\title{
Deposits Pool Management in Islamic Banks in Pakistan: A Case of Term Deposit Receipts (TDRs)
}

\author{
Umar Saeed $^{1 *}$, Muhammad Ismail ${ }^{2}$, Gohar Saleem Parvaiz ${ }^{3}$ \\ $1,2 \mathrm{PhD}$ scholar at Centre for Excellence in Islamic Finance, Institute of Management \\ Sciences, Peshawar, Pakistan \\ ${ }^{3}$ Assistant Professor, Institute of Management Sciences, Peshawar, Pakistan
}

\section{Keywords}

Islamic Banks

Term Deposit Receipts

Mudārabah

PER

IER

\begin{abstract}
This narrative study reports and analyses depoisits pool management in Pakistan, which is an important fund raising instrument used by Islamic banks. The study expamplifies and discusses a complete process starting with the account opening, and its placement in the banks balancesheet, followed by the common pool creation process. It also discusses the role of bank as investor, in addition to a pool manager, and distributation of profits between the the bank and the pool and then among various investers within the pool using the daily average product and the weightages mechanism. Profit Equalization Reserve (PER) and investment Risk Reserve (IRR) are discussed in the context of their respective Shari' ah basis, to develop an overall understanding of term deposit receipts of Islamic Banks.
\end{abstract}

KAUJIE Classification: J0, K2, Q2

JEL Classification: E58, G2

(C) 2018 JIBM. All rights reserved.

\section{INTRODUCTION}

Banks, whether conventional or Islamic, work as intermediaries between the Surplus Spending Units (SSUs) and Deficite Spending Units (DSUs). They perform this intermediation role by accepting deposits from SSUs and financing the DSUs. Among various products and tools available for this purpose are the term deposits taken by issuance of the Term Deposit Receipts (TDRs). Term deposits usually have unique characteristics. For instance, the deposited amount usually cannot be withdrawn before maturity date, or prior to a notice. Otherwise, a penalty is usually imposed for earlier withdrawal. In the competitive market, during the last decade, there has been a change by allowing the depositors early withdrawal without penalty, but at reduced rate applicable to the term, completed by any deposit account.

In case of conventional banking practices, the phrase term deposit refers to a savings account, term deposit, or certificate of deposit that fetchs a fixed rate of interest until a given

${ }^{*}$ Corresponding author: Umar Saeed
${ }^{\dagger}$ Email: saeedorakzai88@gmail.com 
maturity date. Since charging interest is not allowed in Islamic banking, that's why Islamic banks do not raise interest based deposits; they rather get deposits on the basis of muda $\mathrm{arabah}$ and give a profit share to the depositors (Ayub, 2007, p. 359). For the purpose of investment and financing, they avoid investment in such avenues which are somehow linked to Shari 'ah prohibitions (Ullah \& Al-Karaghouli, 2017). The TDR is usually structured on the basis of mudārabah contract. While a bank serves as mudārib (entrepreneur), the depositors provide finance, thus serve as rabb al-māl (funds owners). The Banks may also provide finance, in addition to using the depositors money. The financial profit is shared according to the pre-agreed proportion, while financial loss, if any, has to be borne exclusively by the investor (Ayub, 2007). TDR is also considered as time deposit because the depositer is required to maintain the balance until a given period of time. The deposits against TDRs are repayable subject to a period of notice and not on demand. Every deposit is allocated specific tenure as agreed by the bank and the customer. Both parties are entitled to profit calculated via a weightage system assigned by the bank's management.

By way of TDRs, Islamic banks tend to utilize the surplus liquidity with households and the business units in the society in a Shari 'ah compliant manner and give them a share in profit earned by financing and investments. For subscription of TDR facility/product, a customer needs to visit Islamic bank and undertake some formalities as required by the regulator, the State Bank of Pakistan. Normally, banks use promotion/advertising channels to attract potential customers. A customer may approach an Islamic bank by itself normally called a walk-in customer. However, some customers approach through some references. Similarly, sometime, existing customers want to avail additional banking services or interested to convert the existing deposit into a TDR.

\section{Objective of the Case Article}

- To describe overall process of term deposits and TDRs

- To describe mudāarabah profit and loss distribution mechanism.

- To describe the methodology of various reserves for the risk management related to TDRs and other investment deposits

In the narrative article in hand, we discuss a person, say Mr. Babar, who had been maintaining a Current Account with $\mathrm{ABC}$ Islamic bank. His friends suggested him to maintain an Investment Account by getting a TDR on which he would be getting share in profit based on the Islamic principle of muda arabah. While maintaining a current account, he was not getting any return from $\mathrm{ABC}$ Islamic bank as his deposit amount is considered as a loan for the Bank (Ayub, 2007). Mr. Babar is a well qualified person and had spent most of his time in a foreign country and had no clear idea as to how an Islamic bank would be giving return and that will not be interest, as it is prohibited strictly by Islam. As he was not sure about the Shari 'ah compliance of the new banking system being evolved, he wanted to be convinced, to a certain level at least, that the product he is availing conforms to the Shari' ${ }^{\prime}$ ah principles. This concern was particularly caused due to some discussions he had with different people some of whom 
believed that there was no difference between Islamic and conventional banking as per a common misgiving among the general public (Ayub, 2007, Pp 445-453). After listening to Mr. Babar, the Personal Banking Officer (PBO) thought it necessary to first explain to him what is Islamic banking and how does it work.

\section{The Islamic Banking Model}

Throughout the world, while deposits are raised generally on the basis of mudārabah/ mushärakah (partnership), financing could be provided on partnership model, lease model, sale model, agency model, and the combination of two are more of them (Ullah \& AlKaraghouli, 2017). TDR is a means of mobilization funds from general public under the muda arabah mode of finance. Apart from its relevance to TDR, mudārabah is a very important contract in Islamic banking due to the fact that theoretically it is the mode of finance on which the Islamic banking and finanece is supposed to be built. Therefore, the PBO considered it necessary to introduce Mr. Babar to this concept in detail.

Muda arabah is the major mode used by Islamic banks for getting deposits from the public. Siddiqi (1991) has discussed thoroughly the extended scope of muda rabah. The relationship between depositors and Islamic banks is that of financiers and entrepreneurs (the banks). It is for the Investment Account Holders (IAHs) who wish to get return on their savings and investments by avoiding interest (Ayub, 2013, p. 54; Ullah \& Al-Karaghouli, 2017). All deposits are allocated to various pools, that are used by banks for business. The direct expenses are charged to the pool while administrative expenses are borne by the bank (mudāarib). The net profits are distributed, first between the bank and the pools according to the stipulated ratios, and then among the depositors based on the weighatges system.

In case of losses, if any, the same are distributed among the investors. In case all financing is from the depositors, the bank suffers time and effort loss only. In case, the bank also invests in a pool, the loss is shared as per the ratio of finance provided by it.

In the case of TDR, the investment account holders are the collective investors and the Islamic bank plays the role of fund manager. Now Mr. Babar knew that he will be a rab al-māl under this arrangement while the ABC Islamic banks will be the manager/entrepreneur.

After getting clarification, Mr. Babar further wanted to know how the asset liability mechanism of Islamic banks works. This made the PBO to further explain the balance sheet of a typical Islamic bank by elaborating the financial intermediation function of Islamic banks.

\section{Financial Intermediation of Islamic Banks and their Balance Sheet Modes used on asset side}

As one of their main functions, Islamic Banks and Financial Institutions (IBFIs) play a vital role in utilizing the national resources and savings in an economy efficiently and effectively. When utilizing these resources in income generation activities through financing, IBFIs use both fixed return modes such as mudārabah, ijärah (leasing) and salam etc; that generally create debt, as well as variable return modes including mushārakah, mudārabah and their varients. Fixed, but flexible rate of return is possible in leasing and all such contracts where ijārah (leasing) might be the underlying mode (Ayub, 2007, pp. 297-300). 


\section{Modes used on Deposits/liability side}

On the resource mobilization side, the mudārabah and mushārakah modes are used by Islamic banks. However, the use of mushärakah is rare in contrast to mudārabah. For Current Accounts, generally amānah/wadi' $' a h$ or qard contracts are used and, as susch, the depositors are not entitled to any return. For TDR, mudārabah is the mode most frequently used contract in current Islamic banking system. The Isamic bank and the Investment Account Holders (IAH) share the realized profit in accordance with the ratios agreed between the parties at the time of contracting. The traditional concept of muda arabah in fiqh, where one person provided capital and the other used it for business is applied in Islamic banks but the procedure and mechanism is significantly different from the pure/traditional mudāabah. Hence, while various categories of deposits are shown on liabilities side, assets like (receivables under) mudāarabah, ijārah, salam, istiṣna ${ }^{\prime}, s u k \bar{u} k$ held, etc are shown on assets side of the banlance sheet.

\section{Mechanism of Opening Account for TDR}

Mr. Babar was enlightened suffieicntly on the underlying mechanism and practical aspects of Islamic banks' operation. He also understood to a great extent how the traditional fiqhi mudārabah contracts are utilized for the purpose in contemporary Islamic banks. Now it was the time for PBO to offer and convince Mr. Babar about the most suitable option for him out of the different products offered by the bank. The PBO explained the variety of accounts offered by the bank, namely current account, saving account, and fixed account, along with their respective requirements and the nature of return.

The PBO told Mr. Babar that the TDR would represent a mudārabah or partnership based contract and for getting a TDR, he will need to open an investment account. For this purpose, the PBO then requires the customer to provide some documents and the potential source of cash flow for him. Providing an income proof or cash flow source is declared mandatory by the State Bank of Pakistan. If the customer is a businessman, he is bound to provide proof of this on his letterhead paper. If he was used to be a salaried person, who is now retired, then the pension book will be considered as an evidence for account opening. In case he is currently on job, his salary slip and employer attestation are mandatory for account opening. Typically, the PBO fills customer account opening form and records personal information, address, account type and purpose of account etc. This is first step for availing TDR facility (or any other deposit facility for that matter).

At the second stage, the PBO and customer approach the Account Opening Officer (AOO). They discuss the nature of account intended by the customer. The AOO takes the final decision about the type of account; (in this case, TDR is decided by customer). The AOO further checkes all the necessary documents related to the personal identification of Mr. Babar and other details like his address, income proof, etc. The AOO informs Mr. Babar that he will send the identification documents to his regional office (RO) for verification. The RO will call for verification of the customer's identity (through CNIC) from NADRA. It may also seek verification of other documents if deemed necessary. After receiving verification, 
the AOO will be opening open Mr. Babar's account in a couple of days.

Briefing Mr. Babar about the next stage, he was informed that the manager operations (MO) reviews the account opening form and other documents thoroughlly and assigns an account number to the customer. The customer then deposits some amount at the cash counter to operationalize his account. The AOO then stocks the customer's file in assigned storage lockers. The customer visits the bank along with letter of thanks to receive the check book and applies for ATM services. He fills and signs the ATM form and then the operational officer enters the data into Customer Relationship Management (CRM) software. The ATM department provides ATM card in accordance with the information provided by customer in account opening form. The ATM department shares customer information with Visa, a card services providing institution globally. Once again, the customer visits the bank and receives the card and finally makes a call to calling center of the bank to activate it. The process as indicated above implies that the formalities need to be reduced to a rational level so that opening and operating a bank account could be easier.

\section{TDR Account \& Its Underlying Shari $\bar{\top}^{\circ}$ ah Mode}

TDRs are the important source of funds for the banks and they differ from saving deposits in the way that depositors might not be allowed to withdraw their amount under specific period of time. The saving deposits and time deposits are the remunerative deposits (accounts), because Islamic banks are bound to pay pro rata return to depositors based on their earned profits. According to the AAOIFI standards, remunerative accounts are neither reported as shareholders equities, nor liabilities. They are reported separately somewhere between liabilities and shareholders' equity as investment account holders equities. As such, TDRs issued on the basis of murābahah may not be reported as liability; the same are rather quasi equity of the depositors, parri pasu with the shareholders. Profit allocation between banks' equity and TDR/ investment account holders is crucial as it requires disclosure of information regarding the business and profit sharing ratio or the formula as agreed in the beginning. The PSR between TDR holders and Islamic bank has to be decided and announced at least 3 working days before the beginning of period concerned. Further, no downward revision can be made during the deposit tenor in the PSR agreed with term depositors at the time of acceptance of deposit. As per SBP directives, the mudārib share cannot exceed 50\% of the distributable profit (SBP, 2012).

Ahmad (2013) states that "Deposits, other than current accounts, are classified into three categories: special notice deposits, savings deposits and fixed or term deposits. "There are seven types of fixed or term deposits classified on the basis of their duration ranging from three months to five years or more."

\section{Creatig an Investment Pool}

Turning towards the case of TDR and its peculiar nature, the PBO explained that Islamic banks create a number of investment pools and deploy funds generated from various sources including TDRs. Generally, a Common Pool is created for the purpose, as exemplified in Figure 1 below: 


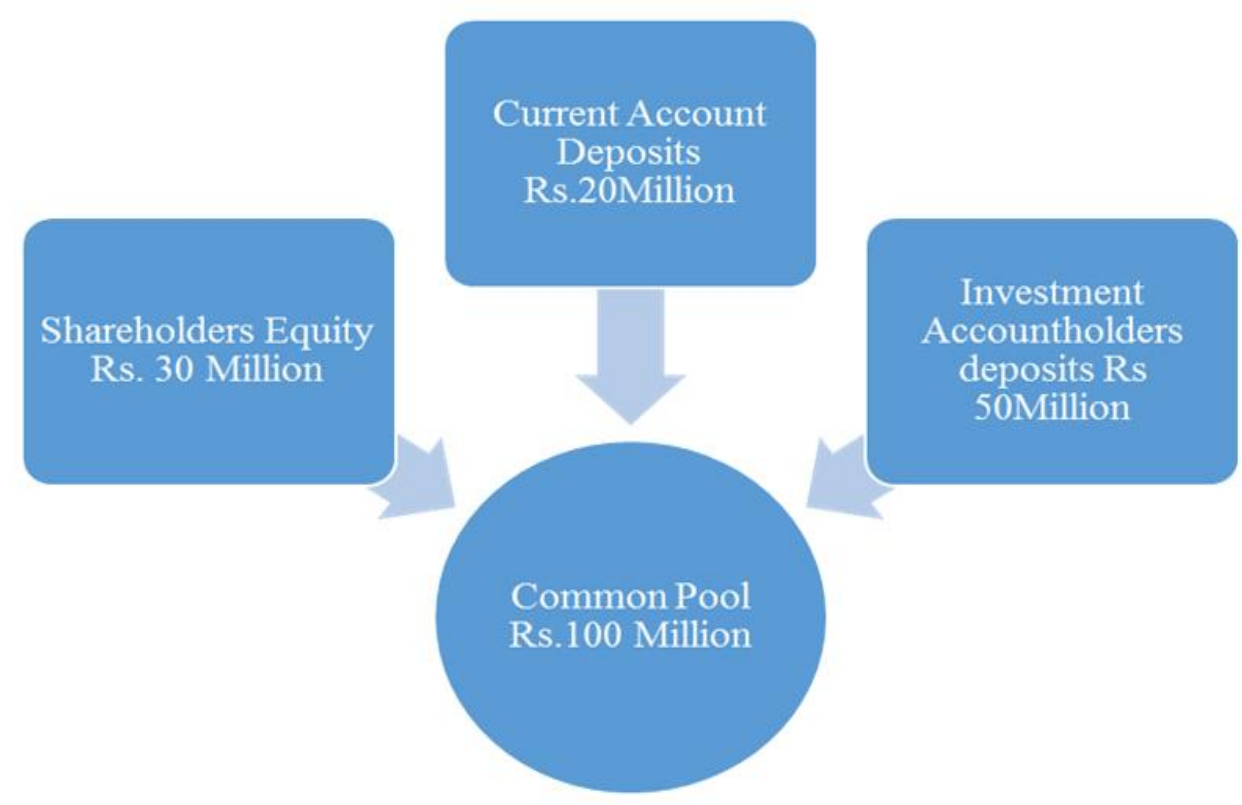

FIGURE 1. The common pool of Rs. 100 million

\section{The Bank as Investor: Division of Profit \& Loss between the Bank and Investors Pool}

In the example discussed here, the bank is also investing its funds, though the same are Current Accounts balances, that are considered as a loan and bank had to pay the amount; as such, accounts are liability of the bank, so such balances are considered as that of the bank itself. Assume that Islamic bank conducts the business and manages the joint investment pool as a mudārib and earns periodic profit of Rs. 10 million. For distribution of said amount of profit between various investors, Islamic bank will take in view its share in the pool's funds. As it has provided 50\% fund (Rs 50 million), half of the profit i.e. Rs 5 million will go to the Islamic bank while the remaining portion of profit, i.e. Rs. 5 million, will be divided between the Islamic bank, as mudārib, and investment accountholders as per predefined ratios.

\section{The Bank As Mudārib: Division of Profit Between the Bank and Investors Pool}

As discussed earlier, that IBFIs have been using different procedures for deposit management and profit allocation and distribution. They have not been consistent with regard to the profit sharing ratios between the banks and the IAHs, weightages assigned to various categories of deposits in terms of size and allocation of assets to various pools. To remain competitive in the market and to manage the Displaced Commercial Risk (DCR), the tool they have been using, seemingly indiscriminately, the hibah in case the profit realized by any pool was less than the market benchmark (Ayub, 2013, p. 52). Suppose, that the mutually agreed ratio between the Islamic bank and investment account holders was 50:50. The banks usually do not simply distribute the profit as per the agreed ratio; rather they take out a portion called PER. The PER is kept from the net income of the pool, prior to the distribution between the bank as muda rib and the pool, i.e. the gross income less direct expenses and losses, if any. The SBP's Islamic banking department has issued the Instructions for Profit and Loss Distribution and Pool Management for Islamic Banking Institutions through the circular 
number 3 of 2012. The instructions outline, that the monthly contribution into PER will not exceed $2 \%$ of net Income, and the accumulated balance of PER shall not exceed $30 \%$ of Islamic Bank's Equity or Islamic Banking Fund (IBF) of the Islamic banking division of the conventional bank. The PER balances are to be used to smooth the returns of deposits and to avoid displace commercial risk. One may, however, argue on the Shari 'ah compliance of this practice.

In the example we are discussing, the gross profit was Rs. 10 million in which Rs 5 million was the mudārabah profit out of which PER @ 2\% is to be kept, it would be Rs. 100,000 in absolute terms. The remaining profit (4.9 million) is available for disctribution among the Bank and the depositors of the pool on the basis of 50:50. Both the Bank and the pool will get Rs. 2,450,000 as profit share for each. Out of the profit distributable among the depositors of the pool, another reserve namely Investment Risk Reserve (IRR) has to be kept for mitigating the risk of capital loss anytime in future. Banks have to develop model and basis to determine the size of the IRR and the periodic contributions to be made to build up the IRR. Till the development of such model, banks may keep up to 1.0 percent of the profit available for distribution amongst the pool's depositors as IRR. The IRR is usually interpreted as a safety net designed to secure investors from unexpected future events that may cause investment losses. Hence, the IRR @1\% will be Rs. 24,500. Afterward, Rs. $2,425,500$ have to be distributed among various categories of depositors whose money has been invested in the pool. This distribution would base on the average daily balances and the weightages assigned to various categories of the deposits.

\section{Shari'ah Justification of PER \& IRR}

Although this much detail was sufficient to understand the economic rationale for PER and IRR, Mr. Babar was uncertain as to how such concepts could be allowed in Shari'ah. This confusion stemmed from the fact that the risks for mitigation of which PER and IRR are designed are related to contemporary banking practices and have not been discussed in the classical literature on mudārabah. Throwing light on this issue, the PBO argued that every fair and reasonable precautionary action taken with mutual consent of stakeholders is permissible in Shari' 'ah . Besides, it is in line with another Shari' 'ah concept of 'mubara'ah' which means "waiving a portion of right to receive profits" (Htay, 2013). Regarding the deduction of reserve, the following view is upheld by the Accounting and Auditing Organization for Islamic Financial Institutions (AAOIFI) in its Shari 'ah standerd no 40:

"3/1/2/3: Deduction of the allocations and reserves relating to the investment, from investment income so as to arrive at distributable profit. In this case, allocations for bad debts and reserve for rate of returns have to be deducted from gross profit, whereas reserve for investment risks has to kept from gross profit, while reserve for investment risks has to be deducted after deduction of the mudārib's share" (AAOIFI, 2015, p. 999).

Similarly, AAOIFI discussed in its Shari 'ah standard no 45 that the basis for the permissibility of deducting reserves from profits is the consent of the IAHs and Islamic financial institutions, in addition to the fact that it strengthens the investment's financial situation (AAOIFI, 2015, p. 1112). 


\section{Profit Distribution Among the Investment Account Holders}

Perhaps the most tricky part of TDRs management is the profit distribution mechanism because even though fixing the profit ratio (PSR) usually seems simple (say $50 \%$ for each party), but, the most technical issue starts after the mudārib's share is taken from the pool's income. For this, a weightage system has been devised based on a general principle that longer the period of the TDR, higher would be weightage assigned to it. But all such information has to be shared with the depositors in advance and the non-disclosure could create the Shari 'ah related issues. Mr. Babar wanted to know as to how the PSR is used to calculate the profits for each depositor. The PBO explained this point through an example.

\section{Example of Daily Average Balance}

Although TDRs are issued for deposits of fixed tenure, but banks in competitive environment many times allow the depositors to withdraw and deposit before maturity. In case of investment accounts, the IAH deposit and withdraw the funds anytime in a month. For the purpose of profit distribution banks use the daily balances. They calculate, through a software, daily closing balances of all investment deposits and find out the average balance during a month. Assume, following is the movement in the month of January in Ahmmad's account (in '000'):

- 01 January - Rs. 100

- 10 January - Rs. 200100 Rs for 9 days

- 20 January - Rs. 250200 Rs for 10 days

- 31 January - Rs. 150250 Rs for 11 days

- Calculation:

$-100 \times 9=900$

$-200 \times 10=2,000$

$-250 \times 11=2,750$

$-150 \times 1=150$

- Average: $5,800 / 31=187.1$ thousand

\section{Weightages and Distribution of Profits \& Losses}

As indicated above, Islamic banks assign weightages to each deposit on the bases of tenure, amount of deposit and profit payment frequency of the account. The depositors with higher amount, reasonable tenure and low frequency of profit payment are allocated high weightages.

The banks usually calculate weighted balance of each deposit as (Actual balance $\times$ weightage). Afterwards, the profit amount for each deposit balance and tenure is calculated as (weighted balance $\div \sum$ of weighted balance $\times$ actual amount of profit of all investment account holders). Then, the rates to be announced by Islamic banks are calculated-[profit amount of each term deposit $\div$ actual balance of deposits]. 


\section{Distribution of Losses}

There is a proper rule for loss distribution in mudārabah according to which losses will be componseted from profit first. Therefore, at first instance, the loss will be offset by profit (Usmani, 2015). This situation occurs when mudārib invests in different projects whereby some projects generate profits while others incur losses. Alternatively, the mudārib invests for different time periods whereby in one period he/she earns profit, but incurs losses in another. In practice, losses do occur in current Islamic banking practices but successive portfolio management eliminates or reduces the chances of losses. If there is no profit earned from any segment of mudārabah investment, then losses will be borne by capital owners.

With respect to the losses in case of TDRS, where Islamic banks establish a common pool, hundreds and thousands of investment account holders become members of this pool and Islamic banks play the role of mudārib as well as sharik (partner) at a time. Besides, the members of common pool are partners to each other, who will bear losses according to their proportion of investment into the common pool.

This case article is useful for:

- Undergratuate and graduate students taking courses in Islamic banking and finance

- Trainess interested in understanding how Islamic banks rise their funds through TDRS

- Shari' 'ah scholors interested in understanding in applied process of mudāarabah via TDRS

- Research students focused on particular instrument of funds mobilization for Islamic banks.

\section{Possible Research Questions /Assignments:}

1) How many stakeholders are involved in the case of mudārabah? Identify and discuss their roles.

2) What alternative Islamic mode could the bank and investment account holder use to fulfill the same need of both the bank and the investment account holder? Comparatively analyze the muda arabah and your proposed alternative Islamic mode.

3) The investment account holders withdraw deposited amount from account earlier maturity; How the banks manage the situation?

4) Why the banks use weightges in TDRs

5) Justify and/or criticize the Shari' 'ah compliance criteria of PER and IRR?

6) What is the difference between 'reserves and provisions'?

\section{Test your understanding on profit distribution:}

Following is the Deposit situation ABC Islamic Bank: 


\section{Fill-in the blanks:}

TABLE 1

Deposit situation ABC Islamic bank

\begin{tabular}{llcc}
\hline \hline Deposit (Tenor) & Deposit & Days with Bank & Av. Daily Balance \\
\hline Months & (Rs.) & & \\
3 & 60,000 & 10 & \\
3 & $1,500,000$ & 20 & \\
Av Deposit & & & \\
6 & 400,000 & 15 & \\
6 & 350,000 & 14 & \\
Av Deposit & & & \\
12 & $2,500,000$ & 10 & \\
12 & 500,000 & 12 \\
Av Deposit & & & \\
\hline
\end{tabular}

\section{Additional Information:}

Total Size of the Asset Pool $=64,193,548$

Total Income $=753,973.0$

Days in Month $=31$

Mudāabah Sharing Ratio $=20 \%$

Weightage of the Equity $=1.0$

Mudārib's Share in profit: $150,794.6$

Poo's Share in the profit: 603,178.4

You may calculate the Income allocation along with annualized rate of return to each type of deposit:

TABLE 2

Income allocation along with annualized rate of return

\begin{tabular}{llclll}
\hline \hline $\begin{array}{l}\text { Tenor } \\
\text { posit } \\
\text { pv. }\end{array}$ & De- & Weightage & Wted. Av & Income Allocation & Rate \\
\hline A & B & C & D= (B*C) & $\begin{array}{l}\mathrm{E}= \\
603 . . / 63623 * 696774.19\end{array}$ \\
3 & & & & $6.70 \%$ \\
6 & 0.6 & & & 7.81 \\
12 & 1.0 & & & \\
Equity & 1.0 & & & \\
Total & & & 603,178 & \\
\hline \hline
\end{tabular}


[Solution with working given below]

\begin{tabular}{llll}
\hline \hline Months & Rs & Days & Avg. Balance \\
\hline 3 & 60,000 & 10 & 19,355 \\
3 & $1,500,000$ & 20 & 967,742
\end{tabular}

\begin{tabular}{llll}
\hline Avg Deposit & & & 987,097 \\
\hline & & & \\
6 & 400,000 & 15 & 193,548 \\
6 & 350,000 & 14 & 158,065
\end{tabular}

\begin{tabular}{llll}
\hline Avg Deposit & & & 351,613 \\
\hline & & & \\
& & & \\
12 & $2,500,000$ & 10 & 806,452 \\
12 & 500,000 & 12 & 193,548 \\
\hline Avg Deposit & & & $1,000,000$ \\
\hline \hline
\end{tabular}

\begin{tabular}{llclccl}
\hline \hline Tenor & Avg Deposit & Weightage & Wted. Avg. & Income Allocation & Profit Rates & \\
\hline 3 & 987,097 & 0.60 & 592,258 & 5,609 & 0.067 & $6.70 \%$ \\
6 & 351,613 & 0.70 & 246,129 & 2,331 & 0.078 & $7.81 \%$ \\
12 & $1,000,000$ & 1.00 & $1,000,000$ & 9,470 & 0.112 & $11.20 \%$ \\
Equity & $61,854,838$ & 1.00 & $61,854,838$ & 585,769 & 0.112 & $11.20 \%$ \\
Total & $64,193,548$ & & $63,693,225$ & 603,178 & & \\
\hline \hline
\end{tabular}

Total Size of Pool $=64193548$

Total Income $=753,973$

Mudārib's Share @ 20\%=150,795

Pools share $=603,178$

\section{REFERENCES AND SUGGESTED READINGS}

AAOIFI (Accounting and Auditing Organization for Islamic Financial Institutions). (2015). Shari'ah Standards (SS: 13). Bahrain: AAOIFI.

Ahmed, H. (2011). Product development in Islamic banking. Edinburgh, UK: Edinburgh Press.

Ayub, M. (2007). Understanding Islamic finance. New York, NY: John Wiley \& Sons. 
Ayub, M. (2013). Profit and loss distribution and pool management framework for IBIs in Pakistan: Progress, issues and implications. Journal of Islamic Business and Management, 3(1), 51-70.

Mansoori, M. T. (2005). Islamic law of contracts and business transactions. Islamabad, Pakistan: Shariah Academy, International Islamic University.

SBP/IBD. (2008). Handbook of Islamic banking products $\mathcal{E}$ services. Karachi, Pakistan: State Bank of Pakistan.

Siddiqui, M. N. (1991). Some economic aspects of murābahah. Review of Islamic Economics, 2(1), 21-34.

State Bank of Pakistan (SBP) (2012). IBD Circular No. 03 of 2012 Dated November 19, 2012. Retrieved from: www.sbp.org.pk

Usmani, I. A. (2015). Meezan banks guide to Islamic banking. Karachi, Pakistan: Maktaba Maariful Quran.

Usmani, T. (2002). Introduction to Islamic finance. Netherlands: Kluwer Law International. Ullah, K., \& Al-Karaghouli, W. (2017). Understanding Islamic financial services. London, UK: KoganPage. 